by the appearance of the $\mathrm{K}$ line on a negative, obtained by Mr. Wright, which was given a very long exposure with the intention of deciding whether this line did, or did not, exist in the Nova spectrum.

The writers suggest that it would now be an exceedingly interesting experiment to test the presence of the absorption lines of calcium, sodium and other elements, in the gaseons nebulæ, by giving exposures long enough to record their continuous spectra.

The Changes in the Nebula surrounding Nova Perser.- - Prof. Louis Bell, writing in the Astrophysical Journal (No. I, vol. xvi.), discredits the "simple reflection" explanation of the changes which have taken place so rapidly in the nebulous matter surrounding the Nova, for the following reasons:- (I) Reflected light would be more or less polarised, and Perrine reports the total absence of polarisation in the light received from this nebula. (2) Reflection does not satisfactorily explain the persistence of strongly illuminated nebulosity at small angular distances from the Nova. (3) At the enormous distances (2 IO light days) from the Nova that some of the bright portions are situated, reflection would not account for the brightness of these parts.

Prof. Bell supports the theory of Seeliger, which accounts for the apparent movements of the brightest portions of the nebula, by supposing that the various parts of this highly tenuous matter are successively lighted up by the effects of a travelling electromagnetic wave-front, and shows that this theory agrees entirely with the observed phenomena.

\section{HUGH MILLER: HIS WORK AND} INFL UENCE. ${ }^{1}$

AONG the picturesque figures that walked the streets of Edinburgh in the middle of last century, one that often caught the notice of the passer-by was that of a man of good height and broad shoulders, clad in a suit of rough tweed, with a shepherd's plaid across his chest and a stout stick in his hand. His shock of sandy-coloured hair escaped from under a soft felthat; his blue eyes, either fixed on the ground or gazing dreamily ahead, seemed to take no heed of their surroundings. His rugged features wore an expression of earnest gravity, softening sometimes into a smile and often suffused with a look of wistful sadness, while the firmly compressed lips betokened strength and determination of character. The springy, elastic step with which he moved swiftly along the crowded pavement was that of the mountaineer rather than of the native of a populous city. A stranger would pause to look after him and to wonder what manner of man this could be. If such a visitor ventured to question one of the passing townsmen, he would be told promptly and with no little pride, "That is Hugh Miller." No further description or explanation would be deemed necessary, for the name had not only grown to be a household word in Edinburgh and over the whole of Scotland, but had now become familiar wherever the English language was spoken, even to the furthest western wilds of Canada and the United States.

A hundred years have passed since this notable man was born, and nearly half that interval has elapsed since he was laid in the grave. The hand of time, that resistlessly winnows the wheat from the chaff of human achievement, has been quietly shaping what will remain as the permanent sum of his work and influence. The temporary and transitory events in his career have already, in large measure, receded into the background. The minor contests in which, from his official position, he was so often forced to engage are mostly forgotten; the greater battles that he fought and won are remembered rather for their broad and brilliant results than for the crowded incidents that gave them such vivid interest at the time. His contemporaries who still survive him-every year a sadly diminishing number-can look back across the half century and mark how the active and strenuous nature whose memory they so fondly cherish, now$$
\text { "Orbs into the perfect star }
$$

A juster estimate can doubtless be formed to-day of what we owe to him than was possible in his lifetime. That the debt is great admits of no dispute, and that it is acknowledged to be

1 An address given at the centenary celebration of the birth of Hugh Miller held in Cromarty on August 22, by Sir Archibald Geikie, D.C.E.,

$$
\text { No. } 1713 \text {, vol. 66] }
$$

due could hardly be more fittingly shown than by the widespread desire which has brought us here to-day from so many distant places in order to raise in the town of his birth, which he made a place of pilgrimage to many a lover of English literature, a visible memorial of him in an institution of which he would himself have heartily approved.

In order adequately to realise the nature and extent of the work achieved by Hugh Miller during his too brief career, we should clearly picture to ourselves the peculiar conditions in which he grew up. Happily he has himself, in one of the most charming pieces of autobiography in the language, told the story of his youth and early manhood. Descended from both a Highland and a Lowland ancestry, he combined in his nature the vivid imagination and poetic impulse of the Celt with the more staid and logical temperament of the Teuton. He was born amidst an English-speaking community, but at a distance of only a few miles from the fringe of the mountainous region within which men use the Gaelic tongue. He knew some survivors of Culloden, and had heard his own grandfather tell how, when a stripling, he watched, from the hills above Cromarty, the smoke wreaths of the battle as they drifted along the ridge on the further side of the Moray Firth. From infancy he was personally familiar with the people of the hills and their traditions, as well as with the ways of the hardy fisher-folk and farmers of the plains. The hereditary predispositions of his mind were in this way fostered by contact with the two races from which they sprang.

Happy in the possession of this racial blending, he was still more fortunate in the place of his birth. He used to remark with satisfaction that both Sir Roderick Murchison and he had been born on the Old Red Sandstone of the Black Isle; but while the career of the author of the "Silurian System" owed practically nothing to his birthplace, which he left while still an infant, Miller's life from beginning to end bore the impress of the surroundings amid which he was born and educated. It would hardly be possible to choose in this country a place of which the varied features are more admirably fitted to stimulate the observing faculties, to foster a love of nature, and to appeal to the poetic imagination than the winding shores, the scarped cliffs, the tangled woods, the wild boulder-strewn moors and distant sweep of blue mountains around Cromarty. And how often and lovingly are these scenes portrayed by him under every varying phase of weather and season! They had stamped themselves into his very soul and had become an integral part of his being.

\section{Haunted him "The sounding cataract}

The

The mountain, and the deep and gloomy wood

An appetite, a feeling, and a love."

But while Nature was his first and best teacher, he has told us in grateful words how much he owed to two uncles-hardworking, sagacious and observant men, by whom his young eyes were trained to discriminate flower and tree, bird and insect, together with the teeming organisms of the shore, and whose high moral worth he, even as a boy, could appreciate. Having learnt to read while still of tender years, he developed an insatiable thirst for books. What he acquired in this way for himself seems to have been at least as useful as the training gained during the rather desultory years spent by him at the town grammar-school. He was an intelligent but wayward boy, as much ahead of his schoolmates in general information as in all madcap adventures among the crags and woods. When the time arrived at which he had to choose his calling in life, he selected an occupation that would still enable him to spend his days in the open air and gratify his overmastering propensity for natural history pursuits. Much to the chagrin of his family he determined to be a stone-mason, and at the age of seventeen was apprenticed to that trade. For some fifteen years he continued to work in quarries and in the erection of buildings in various districts of the north country, and even extended his experience for a short time into Midlothian. Deeply interesting and instructive is the record he has left of these years of mechanical toil. But amidst all the hardships and temptations of the life, the purity and strength of his character bore him nobly through. His keen love of nature and his intense enjoyment of books were a never-failing solace. He continued to gain access to, and even by degrees to possess, a considerable body of the best literature in our language, reading some of his favourite authors over twice in a year. $\mathrm{He}$ thus laid up a 
store of information and allusion which his retentive memory enabled him eventually to turn to excellent advantage.

While still at school he tad gained some notice for the verses which he wrote. In the intervals of his subsequent labours with mallet and chisel, he continued to amuse himself in giving metrical expression to his feelings and reflections, grave or gay. Conscious of his power, though hardly yet aware in what direction it could best be used, he resolved to collect and publish his verses. At the age of seven-and-twenty he accordingly gave to the world a little volume with the title "Poems written in the leisure hours of a Journeyman Mason." Not without some misgiving, however, did he make this first literary venture. Even before the voices of the "chorus of indolent reviewers" could travel up from the south country, with their sententious judgments of the merits and defects of this new peasant-poet, he set himself to prepare some contributions in prose which might perchance afford a better measure of his quality. Some years before that time he had been out all night with the herring fleet, and he now sent to the Inverness Courier some letters descriptive of what he had then seen. These made so favourable an impression that they were soon afterwards reprinted separately. They marked the advent of a writer gifted with no ordinary powers of narration and with the command of a pure, nervous and masculine style. The reception which these letters met with from men in whose judgment and taste he had confidence formed a turning point in his career. He now realised that his true strength lay, not in the writing of verses, but in descriptive prose. Some years, however, still passed before he found the class of subjects on which his pen could most effectively be exercised. In the meantime he began to record the legends and traditions of his native district. Most of these had been familiar to him from childhood, when he heard them from the lips of old grey-headed men and women, but they were dying out of remembrance as the older generations passed away. Part of his leisure for several years was given to this pleasant task, until there grew up under his hand a bulky volume of manuscript. This time he was in no hurry to publish ; the book did not make its appearance until I 835 , as his charming "Scenes and Legends of the North of Scotland." In this work some of the most striking passages were to be found, not so much in the tales themselves which were narrated as in the local colouring and graphic setting that were given to them. The writer displayed a singularly vivid power in the delineation of scenery, and his allusions to the geology $o_{1}$ the district, then almost wholly unknown, attracted attention, since they showed that besides his keen eye for the picturesque above ground, he knew something of the marvels that lay beneath. He was feeling his way to what ultimately became his most cherished and most useful task. He had realised that his main object should be to know what was not generally known, "to stand as an interpreter between nature and the public," and to perform the service of narrating, as pleasingly as he could, the facts which he culled in walks not previously trodden, and of describing, as graphically as might be, the inferences which he drew from them.

Ever after his first day's experience as an apprenticed mason in a stone-quarry, of which he has left more than one impressive account, he was led to interest himself in the diversified characters of the rocks of the district. Even as a boy he had been familiar with the more obvious varieties of stone to be met with in a tract of country wherein the sedimentary formations of the Lowlands and the crystalline masses of the Highlands have been thrown side by side. But he had been attracted to them rather on account of their singular shapes or brilliant colours than from any regard to what might have been their different modes of origin. Now, however, he had discovered that these rocks are really monuments, wherein are recorded portions of the past history of the earth, and he was full of hope that by patient study he might yet be able to decipher them. The supply of elementary treatises and text-books of science, in the present day so abundant, had hardly at that time begun to come into existence. Geology, indeed, had but recently attained a recognised position as a distinct branch of science. And even had the young stone-mason been able to possess himself of the whole of the scanty geological literature of the time, it included no book that would have solved for him the problems that daily confronted him as he pursued his labours in the quarry, or rambled in leisure hours along the shore. The best treatise which could have fallen into his hands and which would have been full of enlightenment and suggestion for him-Playfair's immortal
"Illustrations of the Huttonian Theory"-had appeared seventeen years before; but we have no evidence that it came in his way. $\mathrm{He}$ had laboriously to work out his problems for himself.

Innumerable as are the subjects for geological inquiry offered by the district of Cromarty, it was fortunate for Hugh Miller, and not less so for the cause of science, that chance placed him face to face in the most practical way with the Old Red Sandstone, and that he was, as it were, compelled to attempt to understand its history. While the lessons taught by the strata of the quarry had greatly impressed him, the abundant and wellpreserved fossils among the Lias shales of the Eathie shore, which at spare moments he visited, had deepened that impression. It was while endeavouring to find these shales nearer home, on the western side of the Southern Sutor, that he stumbled upon the clays which contain the fish-bearing nodules of the Old Red Sandstone. This happy discovery, which was made in the autumn of 1830 , the year after the publication of his " Poems," marks an eventful epoch in his life, as well as an important date in the history of geological investigation.

At that time comparatively little was known of the Old Red Sandstone. Its very existence as a distinct geological system was disputed on the continent, where no equivalent for it had been recognised. It was alleged to be a mere local and accidental accumulation, which could hardly be considered as of much historical importance, seeing that no representative of it had been found beyond the British Islands. Yet within the limits of these islands it was certainly known to bulk in no in considerable dimensions, covering many hundreds of square miles and attaining a thickness of more than 10,000 feet. It had been clearly shown by William Smith, the father of English geology, to occupy a definite position beneath the Mountain Limestone and above the ancient "greywacke" which lay at. the base of all the sedimentary series, and he had indicated its range over England and Wales on his map published as far back as I8I5. In Scotland, too, its existence and importance as a mere mass of rock in the general framework of the country had long been recognised. Ami Boué had published in 1820 an excellent account of its igneous rocks, but without any allusion to the organic wonders for which it was yet to become famous. The extraordinary abundance of its fossil fishes, where it spreads over Caithness, had been made known to the world by Murchison in 1826 , and in more detail the following year, when Sedgwick and he read their conjoint paper on the conglomerates and other formations of the north of Scotland. But it may be doubted if any of these publications had found their way to Cromarty when Miller was gathering his first harvest of ichthyolites in the little bay within half a mile of the town. He had passed over that beach many hundreds of times in his boyhood without a suspicion of the treasures wrapped up in the grey concretions that lay tossing in the tideway. On breaking these stones, hoping to meet with a repetition of the Liassic organism with which he had grown familar at Eathie, he found a group of forms wholly different. At each interval of leisure he would repair to the spot, and, digging out the nodules from their matrix of clay, would patiently split them open and arrange them along the higher part of the beach, according to what seemed to be the natural affinities of the fossils enclosed within them. Scouring the parish for fresh exposures of the nodulebearing clay, he was soon rewarded by the discovery of some six or eight additional deposits charged with the same remains. There was a strange fascination in this pursuit. He had, as it were, discovered a new world. No human eye had ever before beheld such strange types of creation. Though he was well acquainted with the marine life of the adjacent firths, he had never seen any creature that in the least resembled them, or served to throw light on their structure.

With no chart or landmark to guide him into this new domain of nature, he continued for years quietly to collect and compare. The first imperfect knowledge which he was able to acquire regarding the few modern representatives of the creatures disinterred by him at Cromarty was derived in $183^{6}$ from a perusal of the well-known memoir by Hibbert on the limestone of Burdiehouse. Next year, however, he made the acquaintance of Dr. Malcolmson, who eventually carried some of his specimens to London and the continent, and was the means of bringing him into correspondence with Murchison and Agassiz. Hugh Miller was thus at last placed in direct communication with the world of science and into relation with the men who were most thoroughly versed in the subjects that had 
so long engrossed his thoughts, and most capable of helping him to clear away the difficulties that beset his progress.

Meanwhile an important change had taken place in his condilion of life. During the year I 834, after having worked for fifteen years in his calling of stone-mason, he was offered the accountantship of the Commercial Bank agency to be opened at Cromalty. This offer, which came to him unasked and unexpected, was a gratifying mark of the esteem and confidence with which his character was regarded. He accepted it, not without some diffidence as to his competence for the duties required. It would, however, retain him in his native town, enable him to marry the accomplished girl to whom he had for years been attached, and afford him opportunity to prosecute the researches in the Old Red Sandstone, of which he had now come to realise the importance. It likewise provided him with leisure to prepare contributions to different periodicals, which, though of no great consequence to his reputation,. were of service in adding to an income narrow enough for the support of a wife and family. These writings had this further advantage, that they gave him a readier command of the pen and accustomed him to deal with lighter as well as with graver subjects of discussion, thus furnishing a useful training for what was ultimately to be the main business of his later life.

At this time ecclesiastical questions occupied public attention in Scotland to the exclusion of almost everything else. The Church was entering on that stormy period which culminated in the great Disruption of 1843 . II ugh Miller, who was at once an earnest Christian and a devoted son of the Church, watched the march of events with the deepest sympathy. As a thoroughly "Establishment man" he had taken but slender interest in the previous Voluntary controversy, but the larger and more vital conflict now in progress filled him with concern. It was his firm conviction that the country contained " no other institution half so valuable as the Church, or in which the people had so large a stake." The anxiety with which the situation impressed him affected his sleep, and he would ask himself, "Can I do nothing for my Church in her hour of peril ?" The answer which he found was to write his famous "Letter from one of the Scotch people to Lord Brougham." This pamphlet was soon after followed by another, entitled "The Whiggism of the Old School, as exemplified in the past history and present position of the Church of Scotland." These writings, so cogent in argument and so vigorous in style, had a wide circulation, and undoubtedly exercised much influence on the progress of the ecclesiastical controversy throughout the country. The leaders of the non-intrusion party, with whose cause he showed such keen and helpful sympathy, soon after the appearance of the first pamphlet invited Miller to confer with them in Edinburgh, and offered him the editorship of their projected newspaper, the Witness. With some misgiving as to his competence to meet all the various demands of a journal that was to appear twice a week, he accepted the proposal. Thus, after his five years' experience as a bank-accountant, he became at the begin ning of $\mathrm{I} 840$, when he was thirty-seven years of age, the editor of an important newspaper, and he retained that position until his death.

Up to this time the name of Hugh Miller was but little known beyond his native district. His political pamphlets first gave it a wide reputation, and thenceforth his conduct of a journal that represented the interests of one of the great parties into which his country was divided kept him constantly before the eyes of the public. The Witness rapidly attained a large circulation. It appealed, not merely to the churchmen whose views it advocated, but to a wide class of readers, who, apart from ecclesiastical polemics, could appreciate its high tone, its sturdy independence, its honesty and candour, and the unusua literary excellence of its leading articles. It not only upheld, but raised the standard of journalism in Scotland. As a great moral force it exercised a healthy influence on the community. There cannot be any doubt that the powerful advocacy of the Witness was one of the main agencies in sustaining the energies of the non-intrusion party and in consolidating the position of the young Free Church. It is my own deep conviction that the debt which that Church owes to Hugh Miller has never yet been adequately acknowledged.

Before he had been many months in the editorial chair he began to publish in the columns of his paper the first of that brilliant succession of geological articles which attracted the attention of men of science, as well as of the general public, and which continued to be a characteristic feature of the Witness up to the end of his life. The first articles, describing his discoveries in the Old Red Sandstone of Cromarty, created not a little sensation among the geologists who had gathered in the year I 840 at the memorable meeting of the British Association at Glasgow. It was there that Agassiz, who had come fresh from the study of Swiss glaciers to the Scottish Highlands, announced that he had found clear evidence that the mountains of this country had once also nourished their glaciers and snowfields. It was then, too, that the same jliustrious naturalist gave the first account of the fossils found by Hugh Miller at Cromarty, one of which he named after its discoverer. In that gathering of eminent men, Murchison declared that the articles which had been appearing in the Witness were "written in a style so beautiful and poetical as to throw plain geologists like himself into the shade." Buckland, famous for his own elequent pages in the Bridgewater Treatise, expressed his unbounded astonish. ment and admiration, affirming that "he would give his left hand to possess such powers of description." The articles were next year collected and expanded into his "Old Red Sandstone, or New Walks in an Old Field"-the first and, in some respects, the freshest and most delightful of all his scientific volumes.

In subsequent years there appeared in the same columns his "Cruise of the Betsy"-a series of papers written among the Western Isles, and full of the poetry and geological charin of that marvellous region; his " Rambles of a Geologist," in which he included the results of his wanderings over Scotland between 1840 and I 848 , and other essays, the more important of which were collected with pious care by his widow and published in a succession of volumes after his death. His "First Impressions of England and its People" appeared in I846, and greatly" increased the reputation of its writer as an observant traveller, an able critic and an accomplished writer, possessing a wide and sympathetic acquaintance with English literature. The "Footprints of the Creator," which followed in 1847 , was of a less popular character. Its detailed account of the structure of some of the fishes of the Old Red Sandstone is, however, of lasting value, though its controversy with the "Vestiges of Creation" has now little more than an historical interest. The "Schools and Schoolmasters," after running as usual through the pages of the newspaper, was issued as a separate volume in I852, and was everywhere hailed as one of the most delightful and instructive of all his works. The "Testimony of the Rocks," with the final proofs of which he was engaged on the last day of his life, was issued a few months after he had been laid to rest beside his friend Chalmers. Altogether of his collected writings, including those that appeared in his lifetime, a series of twelve volumes has been published, but many hundreds of articles of less permanent interest, yet each marked by the distinctive charm of its writer, remain buried in the files of the Witness.

If, from his writings alone, we judge of the extent and value of the work achieved by Hugh Miller, we can have little hesitation in believing that it is mainly his contributions to the literature of science that will hand his name down to future generations. Like so many other men who have attained distinction in the same field, he from the beginning to the end made geology his recreation, in the midst of other paramount preoccupations. It furnished him with solace from the toils of the quarry and the building yard, it supplied him with a healthful relief from the labours of the bank, and when in later years he escaped each autumn for a few weeks of much-needed leisure from the cares and responsibilities of the editor's desk, it led him to ramble at will all over his native country, and brought him into acquaintance with every type of its rocks and its landscapes.

Unquestionably the most original part of his scientific work, that wherein he added most to the sum of acquired knowledge, is to be found in his reconstruction of the extinct types of fishes which he discovered in the Old Red Sandstone. The merit of these labours can hardly be properly appreciated unless it be borne in mind that he came to the study of the subject with no preliminary biological training save what he could pick up for himself from an examination of such denizens of the neighbouring firths as he could meet with. But after prolonged search he could find in these northern seas no living creatures the structure of which afforded him any clue to that of the fossil fishes of Cromarty. Some men had concluded that the organisms were ancient turtles, others that they were crustaceans or even aquatic beetles. He had the sagacity, however, to surmise that they were probably all fishes, and he 
enjoyed the satisfaction afterwards of learning that Agassiz pronounced even the most bizarre amongst them to belong to that great division of the animal kingdom. IYe was guided by his own intuitive conception of what must have been the plan on which these long-vanished types of organic structure had been fashioned. Huxley, who twenty years afterwards had o:casion to subject the Old Red Sands'one fishes to critical study, and who brought to the inquiry atll the resources of moilern bi,s. logy, has left on record the impression made on his mind by a minute revision of IIugh Miller's work. "The more I study the fishes of the "Old Red," he remarks, "the more am I s'ruck with the patience and sagacity manifested in Hugh Miller's researches, and by the natural insight which in his case seems to have supplied the place of special anatonical knowledge." He refers to the "excellent restoration of Osteolepis," in which even some of the minute peculiarities had not escaped nutice, and he declares that IIugh Miller had made known almost the whole organisation of Dipterus, and had thus anticipated the most important part of I'rof. P'ander's labours in the same field, the discinguished Russian palæeontologist not having been aware that the work had already been done in Scotland.

But it is not, in my opinion, by the extent or value of his original contributions to geology that the importance of IIugh Miller's scientific labours and writings should lon measured. Other men, who have left no cunspicuous mark on their time, have surpassed him in these respects. What we more especially owe to him is the a wakening of a widespread interest in the methods and results of scientific inquiry. More than any other author of his day, he laught men to recognise thit beneath the tech. nicalities and jargon that are too apt to conceal the meaning of the facts and inferences which they express, there lie the most vital truths in regard to the world in which we live. He clothed the dry bones of science with living flesh and blood. He made the aspects of past agies to stand out once more before us, as his vivid imagination conceived that they must once have been. He awakened an enthusiasm for geological questions such as had never before existed, and this wave of popular appreciation which he set in motion has never since ceased to pulsate through. out the English-speaking population of the world. II is genial ardour and irresistible cloquence swept away the last remnants of the barrier of orthodux prejudice against geology in this country. The present generation can hardly realise the former strength of that bigotry, or appreciate the merit of the service rendered in the breaking of it down. The well known satirical criticism of the poet Cowper expressed a prevalent feeling among the orthodux of his day, and this feeling was still far from extinct when Miller began to write. I can recall manifestations of it even within my own experience. No one, however, could doubt his absolute orthodoxy, and when the cause of the science was so vigorously espou-ed by him, the voices of the objectors were finally silenced. There was another class of cavillers who looked on geology as a mere collecting of minerals, a kind of laborious trifling concealed under a cover of uncouth technical terms. Their view was well expressed by Wordsworth when he singled out for contemptuous scorn the enthusiast

$$
\begin{aligned}
& \text { "Who with pocket hammer smites the edge } \\
& \text { Of liskless rock or prominent stone, } \\
& \text { Detaching by the stroke } \\
& \text { A chip or splinter, to resolve his doubts, } \\
& \text { And, with that ready answer satisfied, } \\
& \text { The substance classes by some barbarous name } \\
& \text { And hurries on } \\
& \text { He thinks himself enriched, } \\
& \text { Wealthier, and doubtless wiser, than before." }
\end{aligned}
$$

But a champion had now arisen who, as far as might be, discarding technicalities, made even the dullest reader feel that the geologist is the historian of the earth, that he deals with a series of chronicles as real and as decipherable as those that record human events, and that they can be made, not only intelligible, but attractive, as the subjects of simple and eloquent prose.

The absence of technical detail, which makes one of the charms of Hugh Miller's books to the non-scientific reader, may be regarded as a defect by the strict and formal geologist. Like every other branch of science, geology rests on a basis of observation, which frequently depends for its value upon the minute. ness and accuracy of its details. To collect these details is often a laborious task, which is seldom undertaken save by those to whose department of the science they specially belong. A palrontologist cannot be expected to devote his time to the study of the microscopic characters of minerals and rocks. $\mathrm{He}$ leaves that research to the petrographer, who, on the other

NO. I 713 , vor. 66 hand, will not readily embark on an investigation of the minute anatomy of fossil plants or animals. This specialisation, which has always to some extent existed, necessarily becomes more pronounced as science advances. The days are far past for Admirable Crichtons, and it is no longer possible for any one man to be equally versed in every branch of even a single department of natural knowledge.

Hugh Miller's researches among the Old Red S indstone fishes shoved him to the above all a naturalist and palxontologist, capatble of expending any needful amount of patient labour in working out the minutest details of organic structure. In other ficlds of geological inquiry, while he was far from undervaluing the importance of detail, he avoided the recapitulation of it in his writings. It interester him, indeed, only in so far as it enabled him to reach some broad conclusion or to fill in the canvas of srme striking picture of bygone aspects of the earth's surface. Hence he did not apply himself to the minute inves. tigation of problems of geological structure, and when he undertook any inquiry in that dlirection he was apt to start rather from the palæontological than the physical side. Thus the work of his last jears along the shores of the Firth of Forth, wherein he sought to accumulate proofs of the comparatively recent upheaval of the land, was mainly based on the position of shells with reference to their present habirat in the adjacent seas. As a youth enthusiastically greological, I was privileged to enjoy his friendship, sometimes accompany. ing him on an excursion, and al ways spending an evening with him after one of his autumn journeys that we might exchange the results of uur scveral peregrinations. Only a week or two before his death, on the last of those memorable evenings, he hart his trophy of shells spread on the table, which enabicd him to prove that at no very distant date Scolland was cut in two by a seastrait that connected the Firths of Forth and Clyde. He had found marine shells at Bucklyvie, on the tlat ground about micl. way between the two estuaries. Finding I was not quite clear as to the precise geographical position of his shell-bed, he burst out triumphantly with the lines placed by Scott at the head of the chapter in "Rob Roy," which tells of the journey of Bailie Nicol Jarvie and Osbaldistone into the Highlands:

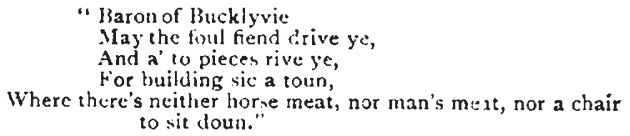

I remember, ton, that on that oc asion I had brought with me the detailed map of Arthur's Seat at Edinburgh, of which I had just completed the geological survey, and I explained to him in some detail what I had found to be the structure of the hill. I Iaving grasped the main succession of the rocks, he with characteristic rapidity passed from the particulars which I had given him to the events of which they were the record, and turning to his daunhter, who was sitting near, he exclaimed to her, "There, Ilarriet, is material for such an essay as has been prescribad to you at school." Then in a few graphic sentences he drew a picture of what seemed to him to have been the history of the old volcano.

While various causes no doubt contributed in this country to the remarkable and rapid increase in the general appreciation of the interest of geological investigation, I feel assured that one of the chief of them has been Hugh Miller's imaginative grasp of the subject and his eloquent advocacy. The personal experience of a single individual can count for litule in an estimate of this kind : lut for what it may be worth, I gladly avail myself of this opportunity to state mine. It was Hugh Miller's "Old Red Sandstone" that first revealed to me the ancient history that might be concealed in the hills around me, and the meanings that might be hidden in the commonest stones beneath my feet. I had been interested in such objects, as boys are apt to be who spend much of their time in the open country. But it was that book which set $m e$ on the path of intelligent inquiry. And this experience must doubtless have been shared by many thousands of his readers who never saw his living face and who never became geologists.

I have alluded to the excellence of his literary style-a characteristic which, unfortunately, is only too rare among writers in science. There can be little doubt that this feature of his work will constitute one of its claims to perpetual recognition. II is early and wide acquaintance with our literature enabled him to intersperse through his pages many an apposite quotation and 
felicitous allusion. He had set before himself as models the best prose writers of the previous century, and the influence of Goldsmith upon him is especially notable. He thus acquired the command of pure, idiomatic and forcible language wherein to clothe the arguments which he wished to enforce, to describe the landscapes which had imprinted themseives like photographs on his memory, and to present restorations of ancient lands and seas which his poetic temperament and powerful imagination called up before his eyes. Moreover, he had a keen sense of humour, which would show itself from time to time, even in the midst of a scientific discussion. He could not bear dulness in others, and strove to avoid it himself. Where his subject might have been apt to grow wearisome, he contrived to lighten it with unexpected flashes of pleasantry or with some pertinent words from a favourite author. This felicitous style seemed so spontaneous, and yet it was in reality the result of the most scrupulous attention. Even in his newspaper articles on the multifarious topics of the passing day, he continued to maintain the same high standard of composition. He has left as his literary monument a series of works that may serve as models of English writing.

In estimating a man's influence on the world we look, not only at his work, but on his character, often the more important and valuable of the two. Judged from this side, Hugh Miller's claims to our regard and admiration are not less strong for what he was than for what he did. Pious and pure-minded, full of generous sympathies, and alive to all that was noblest and best in human life, he was endowed with a manly independence of nature which kept his head erect in every changing phase of his career, and won for him the respect of all, gentle and simple, who came in contact with him. Though naturally robust, his occupation as a mason had left behind some seeds of disease. He was at different times attacked with inflammation of the lungs and other disorders of enfeebled health. His strong sense of duty, however, kept him at his post when prudence earnestly counselled rest. At last the strain became too great, and brought a noble and well-spent life to a sudden and tragic end.

It is to me a valued privilege to take part to-day in the centenary celebration of such a man. The years slip away, and I am probably the only geologist now alive who knew Hugh Miller well. He was my earliest scientific friend. Some boyish articles I had written in an Edinburgh newspaper on a geo. logical excursion to the Isle of Arran had gained me his acquaintance, and ever thereafter I enjoyed his friendship and profited by his encouragement. To his helpful incervention I owed my introduction to Murchison, and thence my entry into the Geological Survey. His death was one of the great bereavements of my youth. It is therefore with heartfelt gratification that here, in his native town, so early familiar to me from his graphic descriptions, I find myself permitted on this public occasion gratefully to express my life-long indebtedness to him for his noble example, for the stimulus of his writings, and for the personal kindness which I received at his hands.

\section{WHAT THE UNITED STATES OF AMERICA IS DOING FOR ANTHROPOLOGY.1}

HAVING recently had the good fortune to pay a somewhat extended visit to the United States of America, I have thought it might not be uninteresting to you to hear what our kinsmen and colleagues across the Atlantic are doing for the furtherance of anthropology.

The means for the advancement of the science of anthropology fall under the following heads :-(I) The collection of information in the field; (2) the publication of such information; (3) the collection of specimens; (4) the preservation of specimens; (5) the publication of museum specimens ; $(6)$ the instruction of students ; $(7)$ independent investigation of collected material.

As no hard and fast line can be drawn between some of these activities, I shall deal first with the museums and with the field work undertaken by the more important institutions in the United States of America, and then very briefly with the teaching of anthropology in the United States.

1 Abridged from the presidential address delivered by Dr. A. C. Haddon, F.R.S. before the Anthropological Institute on January 28 . The addres is published in full in the current number of the Journal of the Institute. NO. I I 3 , vOL. 66$]$

\section{Field Work and Museums.}

It is a glory to the nation of the United States that it has recognised the duty of collecting information about the aboriginal Americans. The twenty or more annual reports published by the Bureau of Ethnology constitute a monument to the intelligence of the Government and of its departmental officials of which their country may well feel proud. Nor does the Bureau of Ethnology neglect the collection of specimens, as is evidenced by the very extensive collections transferred to the National Museum. I cannot, however, refrain from remarking that it seems very strange that the anthropography, or physical anthropology, of the native tribes is entirely neglected by the Bureau, and I know that others share with me the hope that this state of affairs will be remedied.

The head curator of the department of anthropology in the National Museum, Dr. W. H. Holmes, is gradually working out his conception of what his museum should be. His object is twofold: (I) to illustrate the cultural history of mankind; (2) to demonstrate the distinctive characteristics of the various races and people.

(I) Numerous series of objects have been installed to illus. trate the progress of culture, such, for example, as the various stages of evolution from stone implements, on the one hand, to the most modern steel tools and engineering appliances on the other. In this work the curator has been ably helped by the veteran Dr. Otis T. Mason, whose writings on technology are so well appreciated by students. An admirable land transport series has been got together, and one hall is devoted to a wonderful collection illustrating transport by water. There is also an interesting section devoted to comparative religions, of which Dr. Cyrus Adler is the custodian. No Government in the world does so much for ethnology as does that of the United States.

The Free Museum of Science and Art in Philadelphia contains some very valuable and pleasingly arranged collections of Babylonian, Egyptian and Etruscan antiquities. Good representative collections of American ethnology and archæology are being got together, owing to the exertions of Mr. Culin, the director. Of the special collections given to the university, mention need be made only of the collection of gems, of musical instruments and the Furness-Hose collection from Sarawak. In the museum is also to be found Mr. Culin's very instructive and almost exhaustive collection of games, but unfortunately it is stored away in drawers. If this collection was adequately exhibited it would give to the museum a unique position among anthropological museums.

It is instructive to note that although this is a university museum, no support is received from the university, all the scientific work being prosecuted by funds raised from private sources, a result largely due to the enthusiasm of Dr. Sara Y. Stevenson, the energetic secretary of the department.

In I 869 a little band of public-spirited men was created by the Legislature "a body corporate by the name of "the American Museum of Natural History,' to be located in the city of New York, for the purpose of establishing and maintaining in said city, a Museum and Library of Natural History; of encouraging and developing the study of Natural Science; of advancing the general knowledge of kindred subjects, and to that end of furnishing popular instruction and recreation."

A partnership, under sanction of the law, was entered into by the citizens of New York in their corporate capacity with the president and trustees of the museum, it being mutually agreed that the city should pay for the erection of the buildings, their maintenance and protection, while the trustees took upon themselves the responsibility of providing the exhibits, the library, the lectures and other means of instruction and mental recreation. This arrangement is perpetual and irrevocably binding on both parties.

The anthropological department of the museum has accomplished an unprecedented amount of research during the past year, a large sum of money having been received from private sources for the purchase of several important collections of American archæology and ethnology and for the expenses of many expeditions in the field.

The greater part of the anthropological collections in the Yale University Museum are archæological in character. The Peabody Museum of Harvard University is already overcrowded and fresh collections are constantly arriving, which the curator, Prof. F. W. Putnam, is forced to keep in boxes in the store rooms. The main collections are the results of the 